\title{
The Effects of Plasma on Plant Growth, Development, and Sustainability
}

\author{
Bhawana Adhikari ${ }^{1,+}$, Manish Adhikari 1,+(D) and Gyungsoon Park ${ }^{2, *}$ \\ 1 Plasma Bioscience Research Center, Kwangwoon University, Seoul 01897, Korea; \\ bnegi87@gmail.com (B.A.); manishadhikari85@gmail.com (M.A.) \\ 2 Department of Electrical and Biological Physics and Plasma Bioscience Research Center, \\ Kwangwoon University, Seoul 01897, Korea \\ * Correspondence: gyungp@kw.ac.kr; Tel.: +82-2-940-8324 \\ + Equally contributed.
}

Received: 4 August 2020; Accepted: 28 August 2020; Published: 31 August 2020

\begin{abstract}
Cold atmospheric or low pressure plasma has activation effects on seed germination, plant growth and development, and plant sustainability, and prior experimental studies showing these effects are summarized in this review. The accumulated data indicate that the reactive species generated by cold plasma at atmospheric or low pressure may be involved in changing and activating the physical and chemical properties, physiology, and biochemical and molecular processes in plants, which enhances germination, growth, and sustainability. Although laboratory and field experiments are still required, plasma may represent a tool for efficient adaptation to changes in the climate and agricultural environments.
\end{abstract}

Keywords: plasma; seed germination; plant growth; plant sustainability; stress tolerance; reactive species

\section{Introduction}

Agriculture faces many problems due to continuous global population growth, environmental pollution, lack of agricultural land, and climate change. Climate change, in particular, has caused significant reductions in crop yield, threatening global food security [1]. According to the Food and Agriculture Organization (FAO), 20-45\%, 5-50\%, and 20-30\% yield reductions are expected for maize, wheat, and rice, respectively, by 2100 under the current rates of climate change [1]. The distribution of plant pathogens and pests has shifted, the virulence of pathogens has been altered, and new diseases have emerged as a consequence of climatic changes [2,3]. Climate change has also altered the optimal locations of crop culture and reduced the quality and quantity of crop products [4].

Various strategies and technologies have been developed to adapt to changing agricultural environments. Efficient land use and management, altered food demand patterns, and reduced food waste and loss are often suggested as adaptation strategies [5]. Technological crop improvements also provide reliable solutions to overcome environment-associated challenges. Genetic engineering and breeding-based technologies are frequently used to produce crop plants with higher yield and stress tolerance [5]. However, the genetic regulations for crop production and tolerance are complicated processes involving many genes, which complicates crop improvement via genetic manipulation. Safety issues are another barrier that limits the broad application of genetic approaches.

The multi-disciplinary approach has received great attention, and cold atmospheric or low pressure plasma developed by physicists has been actively explored for its agricultural applications [6]. Plasma is an ionized gas produced at room temperature under atmospheric pressure. It generates reactive species, so the activation of plant vitality and the inactivation of microorganisms are frequently 
observed in agricultural applications [6]. Cold atmospheric or low pressure plasma is a potential tool to increase crop plant vitality and production, and several studies have investigated plasma-induced improvements to seed germination, plant growth and reproduction, and plant sustainability. In this review, we summarize the agriculture-based studies of cold atmospheric or low pressure plasma. Due to space limitations, we are unable to review all the published work in this rapidly expanding field.

\section{Effect of Plasma on Seed Germination}

Seeds are the reproductive products of plants which have totipotency, i.e., the capacity to develop into whole plants. Seeds are necessary for plant survival, dispersal, and the maintenance of progeny. At the time of dispersal, seeds undergo a period of dormancy to avoid unfavorable environmental conditions. Many dormant seeds fail to germinate, even if favorable conditions exist. Therefore, it is necessary to break the dormancy stage to increase germination. Other than the environmental factors, the dormant phase and seed germination are influenced by the hard seed coat, the presence of inhibitors, the seed maturation period, the immature embryo, seed coat impermeability to oxygen and water, and hormone imbalances. The phytohormone abscisic acid (ABA) is responsible for maintaining dormancy, whereas gibberellic acid (GA) is responsible for breaking the dormancy phase. These phytohormones are synthesized in the seeds in response to physical factors, and they activate the signaling cascades and enzymes that promote the degradation of seed reserves and initiate germination. Germination occurs in different phases and involves various physiological, biochemical, and molecular events (Figure 1).
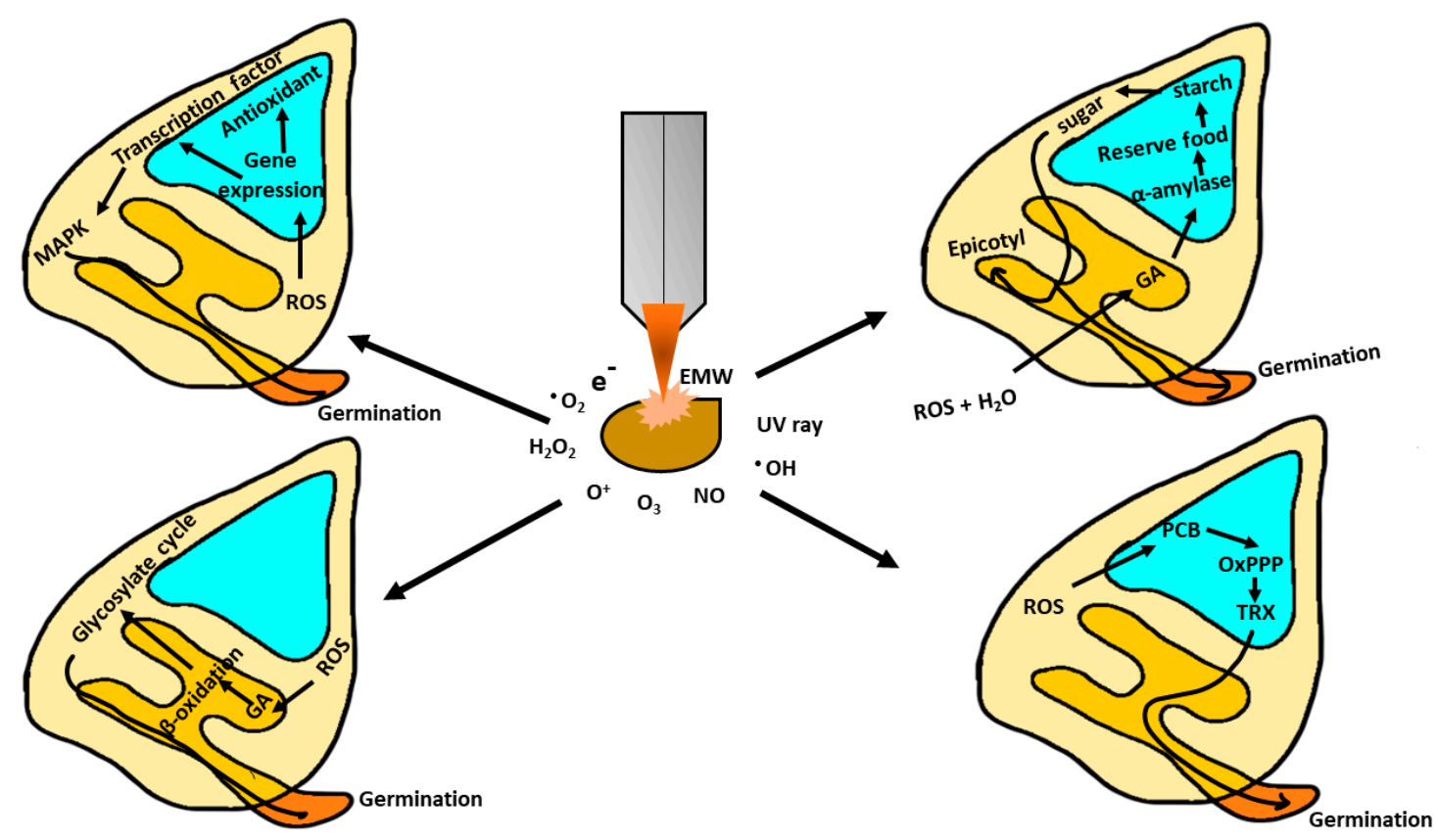

Figure 1. Plausible events of seed germination initiated by plasma seed priming. Plasma treatment causes mechanical damage and facilitates a redox environment for the seed. This redox environment induces different pathways of seed germination. EMW: Electromagnetic wave, GA: Gibberellic acid, MAPK: Mitogen activated protein kinase, OxPPP: Oxidative pentose phosphate pathway, PCB: Protein carbonylation, TRX: Thioredoxin.

Various seed treatment procedures have been applied to overcome dormancy. Popular seed treatment or priming methods, such as scarification, stratification, and chemical treatments, are used to induce germination in dormant seeds [7]. Cold (non-thermal) atmospheric or low pressure plasma is a new technology to enhance seed germination (Tables 1 and 2), and seed treatment involves (1) direct exposure to plasma (Table 1) or (2) indirect exposure via plasma-treated water and solutions (Table 2). 
Table 1. Effects of direct plasma on plant germination, growth, and physiology.

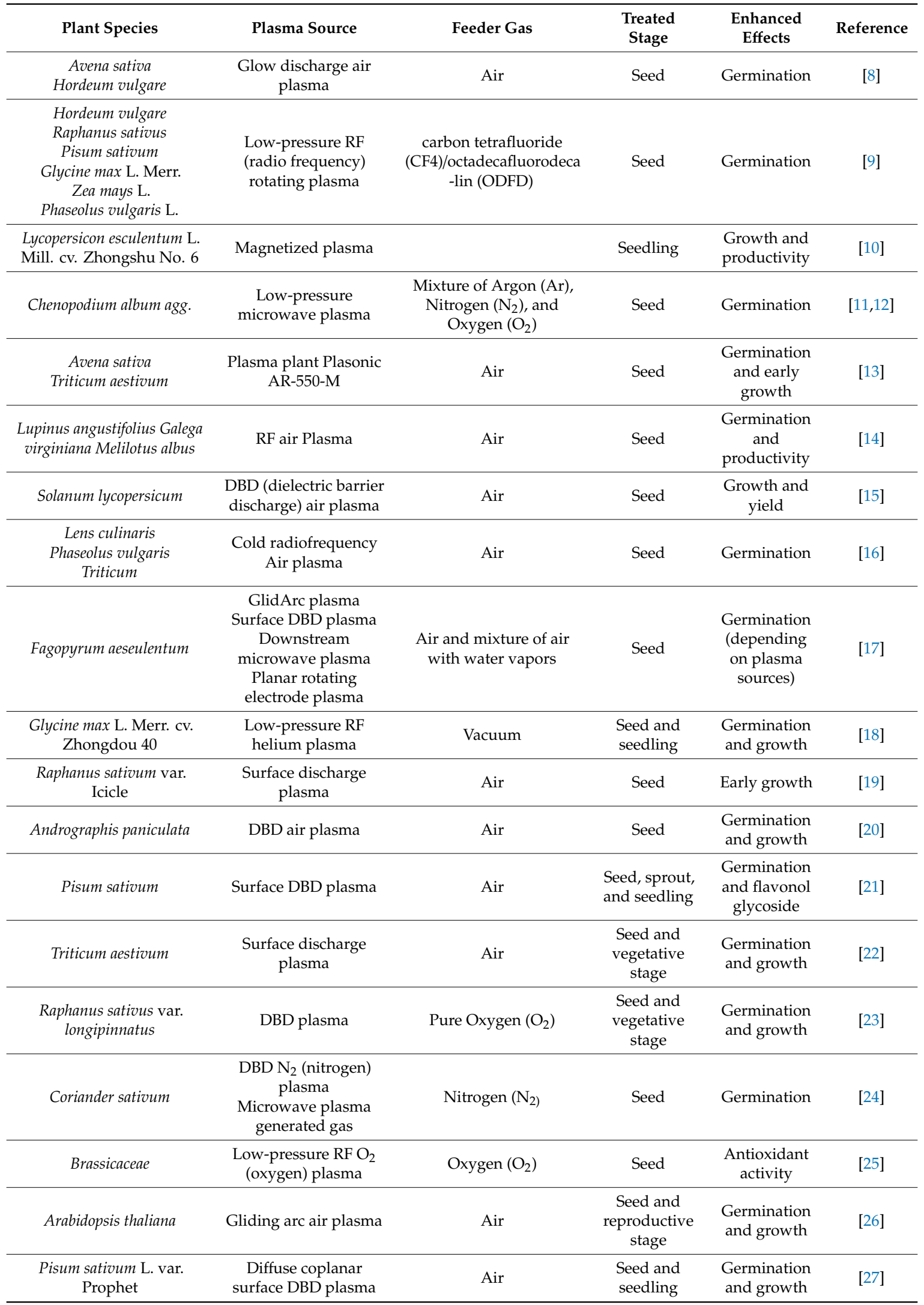


Table 1. Cont

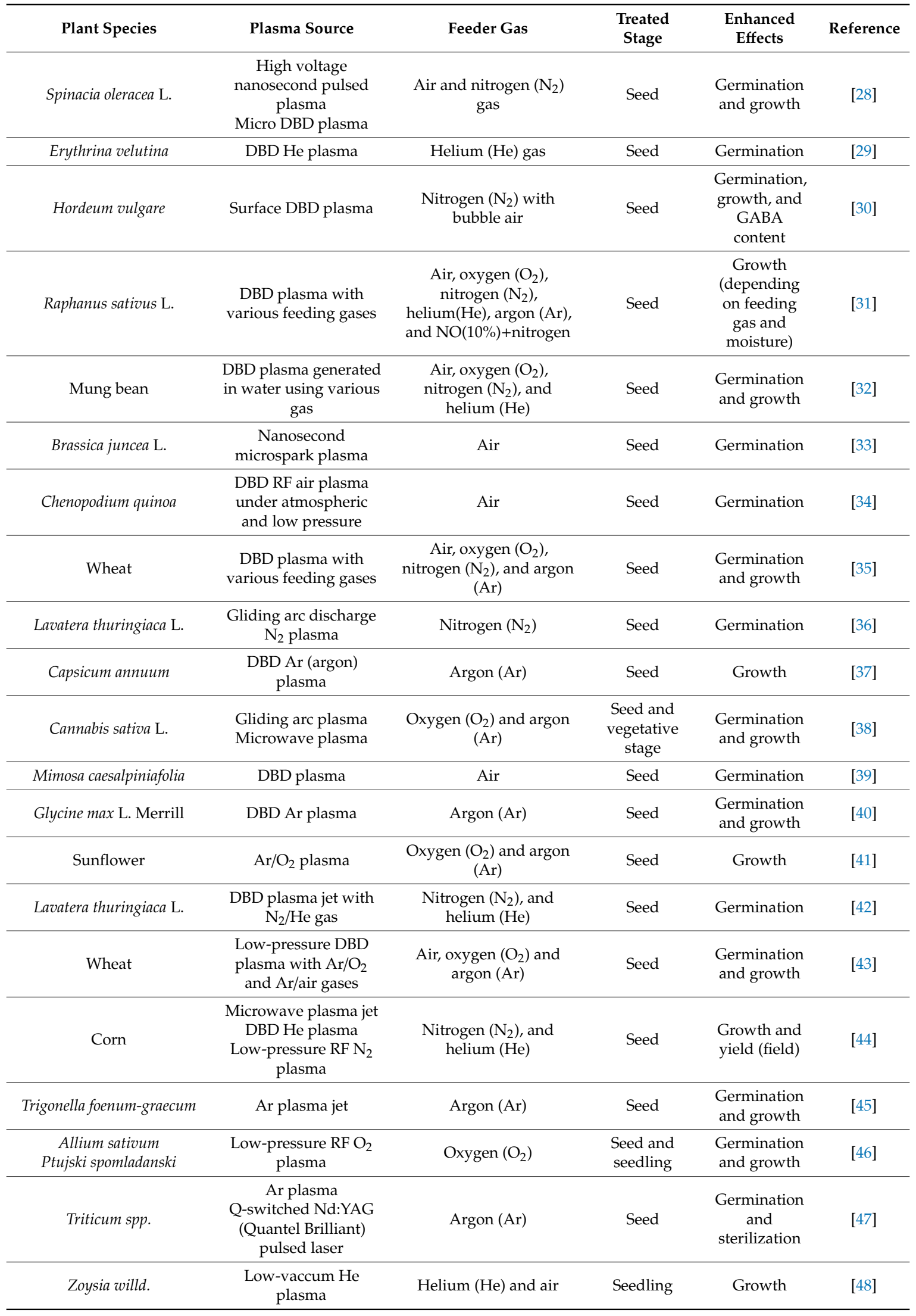


Table 1. Cont

\begin{tabular}{|c|c|c|c|c|c|}
\hline Plant Species & Plasma Source & Feeder Gas & $\begin{array}{l}\text { Treated } \\
\text { Stage }\end{array}$ & $\begin{array}{l}\text { Enhanced } \\
\text { Effects }\end{array}$ & Reference \\
\hline Glycine max L. Merrill & DBD plasma & $\begin{array}{l}\text { Oxygen }\left(\mathrm{O}_{2}\right) \text { and } \\
\text { nitrogen }\left(\mathrm{N}_{2}\right)\end{array}$ & $\begin{array}{l}\text { Seed and } \\
\text { seedling }\end{array}$ & $\begin{array}{l}\text { Germination } \\
\text { and growth }\end{array}$ & [49] \\
\hline $\begin{array}{l}\text { Cucurbita pepo L. cv. } \\
\text { Cinderella } \\
\text { Cucurbita maxima L. cv. } \\
\text { Jarrahdale } \\
\text { Cucurbita maxima L.cv. } \\
\text { Warty Goblin }\end{array}$ & $\begin{array}{l}\text { Cold atmospheric } \\
\text { pressure plasma }\end{array}$ & $\begin{array}{l}\text { Helium (He) and argon } \\
\text { (Ar) }\end{array}$ & Seed & Germination & [50] \\
\hline Cichorium intybus & $\begin{array}{l}\text { DBD plasma (Model } \\
\text { PS200) }\end{array}$ & Argon (Ar) & $\begin{array}{l}\text { Seed and } \\
\text { seedling }\end{array}$ & $\begin{array}{l}\text { Germination, } \\
\text { growth, and } \\
\text { flowering }\end{array}$ & [51] \\
\hline Ocimum basilicum & $\begin{array}{l}\text { Volume barrier } \\
\text { discharge plasma }\end{array}$ & Humid Air ( $40 \%$ RH) & Seed & Germination & [52] \\
\hline Catharanthus roseus & DBD plasma & Argon (Ar) & Seed & $\begin{array}{l}\text { Growth and } \\
\text { physiology }\end{array}$ & [53] \\
\hline Vitis vinifera & DBD Ar plasma & Argon (Ar) & $\begin{array}{l}\text { Seed and } \\
\text { seedling }\end{array}$ & $\begin{array}{l}\text { Germination } \\
\text { and growth }\end{array}$ & [54] \\
\hline
\end{tabular}

Table 2. Effects of plasma treated water/solution on plant germination, growth, and physiology.

\begin{tabular}{|c|c|c|c|c|c|}
\hline Plant Species & Plasma Source & Feeder Gas & $\begin{array}{l}\text { Treated } \\
\text { Stage }\end{array}$ & $\begin{array}{l}\text { Enhanced } \\
\text { Effects }\end{array}$ & Reference \\
\hline $\begin{array}{l}\text { Citrullus lanatus } \\
\text { Zinnia peruviana } \\
\text { Medicago sativa } \\
\text { Phaseolus cocconeus }\end{array}$ & Plasma-treated water & Air & $\begin{array}{l}\text { Vegetative } \\
\text { stage }\end{array}$ & Growth & [55] \\
\hline $\begin{array}{c}\text { Janie marigold } \\
\text { Better Boy tomato } \\
\text { Early Scarlet radish }\end{array}$ & Plasma-treated water & Air & $\begin{array}{l}\text { Seed and } \\
\text { seedling }\end{array}$ & Growth & [56] \\
\hline $\begin{array}{l}\text { Raphanus satious } \\
\text { Solanum lycopersicum } \\
\text { Capsicum annum }\end{array}$ & $\begin{array}{l}\text { DBD air plasma and } \\
\text { Plasma activated water }\end{array}$ & Air & $\begin{array}{l}\text { Seed and } \\
\text { vegetative } \\
\text { stage }\end{array}$ & $\begin{array}{l}\text { Germination } \\
\text { and growth }\end{array}$ & [57] \\
\hline Arabidopsis thaliana & $\begin{array}{c}\text { DBD air and He } \\
\text { (helium) plasma } \\
\text { Plasma-treated water }\end{array}$ & Air and Helium $(\mathrm{He})$ & $\begin{array}{l}\text { Seed and } \\
\text { seedling }\end{array}$ & $\begin{array}{l}\text { Germination } \\
\text { and growth }\end{array}$ & [58] \\
\hline Glycine max L. Merrill & Plasma-treated water & Air & Seed & $\begin{array}{l}\text { Growth and } \\
\text { quality }\end{array}$ & {$[60]$} \\
\hline Solanum lycopersicum & Plasma-treated water & Air & Seedling & Growth & {$[61]$} \\
\hline Pisum satioum L. & $\begin{array}{c}\text { DBD plasma } \\
\text { Plasma-treated tap } \\
\text { water }\end{array}$ & Air & $\begin{array}{l}\text { Seed and } \\
\text { seedling }\end{array}$ & $\begin{array}{l}\text { Germination, } \\
\text { growth, and } \\
\text { flowering }\end{array}$ & [62] \\
\hline Radish sprout & $\begin{array}{c}\text { Plasma-treated organic } \\
\text { solutions }\end{array}$ & $\begin{array}{l}\text { Argon }(\mathrm{Ar}) \text { and oxygen } \\
\left(\mathrm{O}_{2}\right) \text { mixture }\end{array}$ & Seedling & Growth & [63] \\
\hline Spinacia oleracea L. & Plasma-treated water & $\begin{array}{c}\text { Mixture of oxygen }\left(\mathrm{O}_{2}\right) \\
\text { and nitrogen }\left(\mathrm{N}_{2}\right)\end{array}$ & Seed & Growth & {$[64]$} \\
\hline Mung bean & Plasma-treated water & $\begin{array}{l}\text { Air, oxygen }\left(\mathrm{O}_{2}\right), \\
\text { nitrogen }\left(\mathrm{N}_{2}\right), \text { and } \\
\text { helium }(\mathrm{He})\end{array}$ & Seed & $\begin{array}{l}\text { Germination } \\
\text { and disease } \\
\text { tolerance }\end{array}$ & [66] \\
\hline
\end{tabular}


The first reported case of plasma application to seeds was in a US patent by Krapivina et al. [67], where cold atmospheric pressure plasma generated from a mixture of inorganic gases (atmospheric air, oxygen, and nitrogen) was applied to soybean seeds for 5 to $300 \mathrm{~s}$ and the germination and growth were enhanced [67]. In the past 20 years, various plasma sources (dielectric barrier discharge (DBD) jet plasma, microwave discharge, radio-frequency (RF) discharge, gliding discharge) have been developed and used for treating vegetables (tomato, radish, coriander, green peas, and sunflower) and crops (rapeseed, cotton, maize, oat, wheat, mustard, soybean, legumes, and honey clover) (Table 1). Plasma treatment (direct or indirect) has enhanced seed germination in most studies, although no changes in the germination percentage were observed in several studies $[15,19,41,44,56,59,64]$. Plasma promoted the germination speed, overall germination percentage, or both.

Studies have also demonstrated variable effects on seed germination depending on the plasma sources, plant species, treatment time, feeding gases, and moisture content. Šerá et al. [17] compared different plasma sources for buckwheat seed germination and found that a GlidArc plasma source with an air feeder gas induced improved germination compared to downstream microwave plasma, planar rotating electrode plasma, and surface dielectric barrier discharge plasma. Other studies have reported variations in seed germination efficiency among plant species when treated with the same plasma source (Tables 1 and 2) $[9,13,14,16,46,50,56,57,65]$. Most studies identified an optimal treatment time for the best germination efficiency for each plant species and plasma source. Effects of the feeding gases on the plasma-mediated seed germination have also been reported. Zhou et al. [32] found that mung bean seed germination was most efficient with microplasma generated in an aqueous solution using oxygen as the feeding gas, as opposed to helium, nitrogen, and air. Meng et al. [35] reported germination increases of 24,28 , and $35.5 \%$ for DBD plasma-treated wheat seeds with air, nitrogen, and argon feeding gases, respectively. Most studies have been under laboratory conditions, but field-based investigations have also been reported [14,44]. Filatova et al. [14] observed a 10-20\% increase in the field germination capacity of soy, honey clover, and catgut seeds with microwave plasma treatment, whereas Ahn et al. [44] did not observe any changes in the germination percentage.

The mechanisms of enhanced seed germination by plasma have been thoroughly investigated. The most frequently reported factors are changes in the physical and chemical properties of the seed coat or surface. Physical and chemical changes to the seed surface can result in elevated hydrophilicity and water permeability that enhances water imbibition, which is required for seed germination. Increased hydrophilicity and water permeability of the seed surface after plasma treatment has been frequently observed $[16,68,69]$. Chemical changes and leaching of the seed surface membrane have also been analyzed in many studies $[14,18,34,42,68]$. Cold atmospheric pressure plasma decreases the water contact angle from $115^{\circ}$ to $0^{\circ}$ and modulates the hydrophilicity of the seed surface, which increases the uptake of water and initiates subsequent biochemical processes [16]. Similarly, Ling et al. [18] reported that cold plasma treatment decreases the contact angle of soybean seeds from $70.14^{\circ}$ to $20.94^{\circ}$. There is abundant data to support the plasma-induced changes in the physicochemical properties of the seed surface and the increases in water absorption. However, enhanced seed germination was also observed without increased hydrophilicity of the seed surface [34]. The surface of quinoa seeds treated with RF plasma was chemically modified, but the hydrophilicity of the seed surface did not change. Nitrogen oxide $\left(\mathrm{NO}_{\mathrm{x}}{ }^{-}\right)$and potassium $\left(\mathrm{K}^{+}\right)$ions accumulated on the seed surface via chemical alterations from the plasma treatment and penetrated the seeds after water addition, providing nutrients for seed germination. Another possible mechanism for plasma-induced enhanced seed germination is that the biochemical and molecular processes inside the seed are activated by plasma generated reactive oxygen and nitrogen species (RONS). Plasma generates a diverse range of RONS, depending on the feeder gas. These RONS can act as signaling molecules and initiate a germination cascade [70]. Reactive oxygen species (ROS) facilitate the oxidation of the aleurone layer and the mobilization food reserves during seed germination. Mildažienè et al. [71] showed that RF cold plasma (at low pressure) treatment $(7 \mathrm{~min}$ ) increased the GA (gibberellic acid) content of sunflower seeds and increased the germination rate by $10-24 \%$. Increased GA promotes the activity of $\alpha$-amylase, which degrades 
complex starches to metabolize sugar to initiate the germination process [71]. Accumulation of the $\mathrm{GA}_{3}$ germination hormone and amylolytic mRNA in spinach seeds treated with DBD plasma has also been reported [28]. Rahman et al. [43] detected high concentrations of hydrogen peroxide $\left(\mathrm{H}_{2} \mathrm{O}_{2}\right)$ in cold plasma (Ar/Air, at low pressure) treated seeds and concluded that $\mathrm{H}_{2} \mathrm{O}_{2}$ is a signaling molecule that stimulates seed germination. Hydrogen peroxide serves to maintain a low ABA/GA ratio, which promotes the activation of amylase, the mobilization of food reserves, and the low production of antioxidant enzymes. Nitric oxide $(\mathrm{NO})$ is another reactive species that plays a regulatory role in seed germination. NO regulates the production of $\mathrm{ABA}$, a vital phytohormone that initiates germination and breaks dormancy. In plants, $\mathrm{NO}$ is produced from the reduction of nitrate $\left(\mathrm{NO}_{3}{ }^{-}\right)$to nitrite $\left(\mathrm{NO}_{2}{ }^{-}\right)$ by nitrate reductase. Hence, $\mathrm{NO}_{3}{ }^{-}$in plasma-activated water is primarily responsible for enhanced seed germination [57]. A model of the plasma effects on seed germination and the possible molecular and biochemical events is presented in Figure 1.

\section{Effects of Plasma on Plant Vegetative Growth and Reproduction}

The life cycle of plants is divided into three distinct phases: vegetative, reproductive, and seed formation, followed by senescence. Vegetative growth is an important phase in which plants perform photosynthesis, increase their biomass, synthesize the reserve food, and prepare for reproduction. It is also a very sensitive stage because growth is influenced by environmental factors (i.e., heat, drought, pathogen, alkalinity, UV rays) and biological stimuli. Overall crop productivity depends on the vegetative growth phase, and, therefore, the regulation of vegetative growth is critical for plant development and survival [72].

Plasma can regulate the vegetative growth phase of plants, and plasma seed treatment has long-term effects on the early vegetative growth, as reported in several studies (Table 1). Plasma treatment promotes seed germination and subsequent seedling growth, increasing the length and biomass of seedlings (Table 1). As mentioned earlier, enhanced seedling growth without changes to the germination efficiency has been also observed after plasma treatment $[15,19,41,44,56,59,64]$. Plasma treatment at the seedling stage has also reported, which promoted seedling growth $[10,48,55,61,63]$. As for seed germination, the effects of plasma on seedling growth varies with the plasma dose, treatment time, feeding gases, and moisture. Extended plasma exposure or high power or atmospheric pressure reduced seedling growth; wheat seeds treated for $3 \mathrm{~min}$ had higher sprout biomass than seeds treated for 10, 20, or $40 \mathrm{~min}$ [13]. Milder plasma treatments (2.7 W) accelerates early growth and increases the root to shoot ratio [22]. Sarinont et al. [31] investigated the effects of feeding gases and moisture on plasma-mediated seedling growth and found that DBD plasma-treated radish seeds had better seedling growth when air, oxygen $\left(\mathrm{O}_{2}\right)$, nitric oxide $(\mathrm{NO})(10 \%)$, and nitrogen $\left(\mathrm{N}_{2}\right)$ were used as the feeding gases (rather than $\mathrm{N}_{2}$, helium (He), and argon (Ar)). Additional moisture during plasma treatment also accelerated the growth enhancement effects.

Compared to vegetative growth, the effects of plasma on flowering and fruit production have rarely been reported. Studies have shown that plasma seed treatment has positive effects on the reproductive stage and harvesting product of tomatoes, soybeans, and peanuts [10,49]. A field study of okra (Abelmoschus esculentus) in India, found that cold low pressure plasma seed treatment improved different agronomic attributes, including the harvesting time, 50\% flowering time, flower number, fruit number and weight, and okra yield [73]. Recently, Li et al. [74] reported increase in pod numbers $(13.8 \%)$ and grain weight $(8.2 \%)$ after priming oilseed rape plants with cold low pressure plasma at the reproduction stage. In another report, cold atmospheric pressure plasma seed priming increased the flower number $(41.5 \%)$ and fresh weight $(24 \%)$ in Cichorium intybus [51]. Cold atmospheric pressure plasma treatment alone or as a co-treatment with multi-walled carbon nanotubes increased the flower number and diameter of melons, which resulted in more melon fruits [75].

When investigating the mechanism of plasma action on seedling growth, many reports have focused on the increased nitrogen nutrient levels, changes in the amount growth hormones and other physiological processes, and the activation of growth-related gene expression. These mechanisms are 
likely related to the plasma-generated reactive species. Plasma-generated reactive species can produce nitrogen species, such as $\mathrm{NO}_{2}{ }^{-}$and $\mathrm{NO}_{3}{ }^{-}$, after interacting with water. Plasma-treated water acts as a nitrogen fertilizer and is responsible for growth induction in seedlings [57]. Other reactive species, such as $\mathrm{H}_{2} \mathrm{O}_{2}$ and $\mathrm{NO}$, can act as growth stimulators. These reactive species may disturb redox homeostasis and trigger mild oxidative stress in plants at the vegetative and reproductive stages. Elevated in situ $\mathrm{H}_{2} \mathrm{O}_{2}$ and $\mathrm{NO}_{\mathrm{x}}$ concentrations in tomato seedlings in response to plasma-activated water (PAW) was detected by Adhikari et al. [61]. Similar observations the accumulation of RONS in response to plasma treatment in plants have also been reported in other studies [43,54]. The impact of RONS on plant development is well known [76,77], so plasma-generated RONS may similarly influence plant growth and development. Redox reactions play an important role in the cell cycle and cytokinesis. Many small antioxidants (i.e., ascorbate and glutathione) are essential for the cell cycle and act as redox buffers [78,79]. A study of wheat (Triticum sp.) and Arabidopsis roots suggests that the chemical impediment of ROS disturbs microtubule assembly and promotes microtubule formation in the root tip cells. This disturbance to tubulin organization leads to a distorted cytokinesis process [80]. ROS, such as $\mathrm{H}_{2} \mathrm{O}_{2}$, hydroxyl radical $\left(\mathrm{OH}^{\bullet}\right)$, and superoxide $\left(\mathrm{O}_{2}{ }^{-}\right.$, affect cell expansion via their control of the cell wall rigidity. Peroxidase in the apoplasts maintains the $\mathrm{H}_{2} \mathrm{O}_{2}$ level, regulates the crosslinking of phenolics and extensins, and maintains the cell wall rigidity. In contrast, $\mathrm{OH}^{\bullet}$ oxidizes polysaccharides (e.g., xyloglucans and pectins) and facilitates cell wall loosening [76]. Another study showed that the $\mathrm{O}_{2}{ }^{-}$- gradient in the meristem of the roots can play a role in cell division-high $\mathrm{O}_{2}{ }^{-}$. levels are present in root tips, the highest cell division zone, and the peripheral elongation zone has high $\mathrm{H}_{2} \mathrm{O}_{2}$ levels [81]. In Arabidopsis, the ROS content varies during floral bud formation and maturation, indicating the crucial role of ROS during flower development. In rice, the MADS3 gene, which is responsible for stamen formation during early floral bud development, regulates the $\mathrm{O}_{2}{ }^{-}$• concentration. Abnormal MADS3 expression causes pollen sterility by accumulating $\mathrm{O}_{2}{ }^{-}$- [82]. ROS can crosstalk with phytohormones and influence plant growth and development. In the roots, meristem cell growth is influenced by the interplay of $\mathrm{H}_{2} \mathrm{O}_{2}$ and brassinosteroids (BRs); intracellular $\mathrm{H}_{2} \mathrm{O}_{2}$ induces the binding of $\mathrm{BR}$ to its receptor kinase BRI. $\mathrm{H}_{2} \mathrm{O}_{2}$ can oxidize BZR1 (Brassinazole-Resistant 1) and BES1 (Brassinosteroid insensitive 1-Emssuppressor 1), the key transcription factors of BR signaling, and modify their activities. BZR1 interacts with PIF4 (Phytochrome Interacting Factor 4) and ARF6 (Auxin Response Factor 6), which are responsible for promoting meristem growth and development [83]. The redox reaction and ROS also regulate the post-translational modification of histones, transcription factors, and the chemical modifications of the nitrogenous DNA bases. Therefore, ROS epigenetically regulates plant growth. Under oxidative stress, ROS downregulates the histone demethylase gene, interacts with DME1 (DNA methylase), and epigenetically modifies the stress response of plants [77].

Seed reserve food utilization and the contents of soluble sugar and protein in seedlings are elevated after plasma treatments [84]. Cold atmospheric pressure plasma treatment of seeds affects the growth hormone concentration in the vegetative stage. Stolárik et al. [27] observed that the concentration of auxin (IAA) was upregulated in 14- and 21-day-old seedlings exposed to LTP (low-thermal plasma) for $120 \mathrm{~s}$ and $600 \mathrm{~s}$ at the seed stage. Interestingly, the cytokinin content was also significantly increased in 14 days old seedlings exposed to LTP for $120 \mathrm{~s}$ (compared to non-exposed seedlings) [27]. Other reports suggest that the redox homeostasis of plants is modified by cold atmospheric or low pressure plasma treatment. The modulation of superoxide dismutase (SOD), ascorbate peroxidase (APX), and chloramphenicol acetyltransferase (CAT) enzyme activities was observed in wheat plants after low pressure DBD plasma exposure [43]. Likewise, changes in the antioxidant (proline, ascorbic, guaiacol peroxidase, phenylalanine ammonia-lyase, phenolic, and flavonoid) status were also observed in plants at the vegetative stage after cold atmospheric pressure plasma treatment $[40,61,85,86]$. The expression patterns of different growth-regulating genes in response to cold atmospheric pressure plasma treatment have been investigated-argon plasma downregulates the expression of the methylation-related genes in soybeans and epigenetically regulates the expression of the metabolism-related genes [40]. 
The underlying mechanisms of RONS in plant growth and development are well known, and enormous amounts of information are available. As indicated by several studies, cold plasma and plasma-activated solutions can act as oxidative stimulants and disturb redox equilibrium. Redox non-equilibrium promotes the interaction of RONS with biomolecules, leading to oxidative modification or damage. Elevated RONS can also crosstalk with other metabolic reactions, phytohormones, and growth and development signaling cascades that change the plant across different physiological, biochemical, and molecular levels (Figure 2).

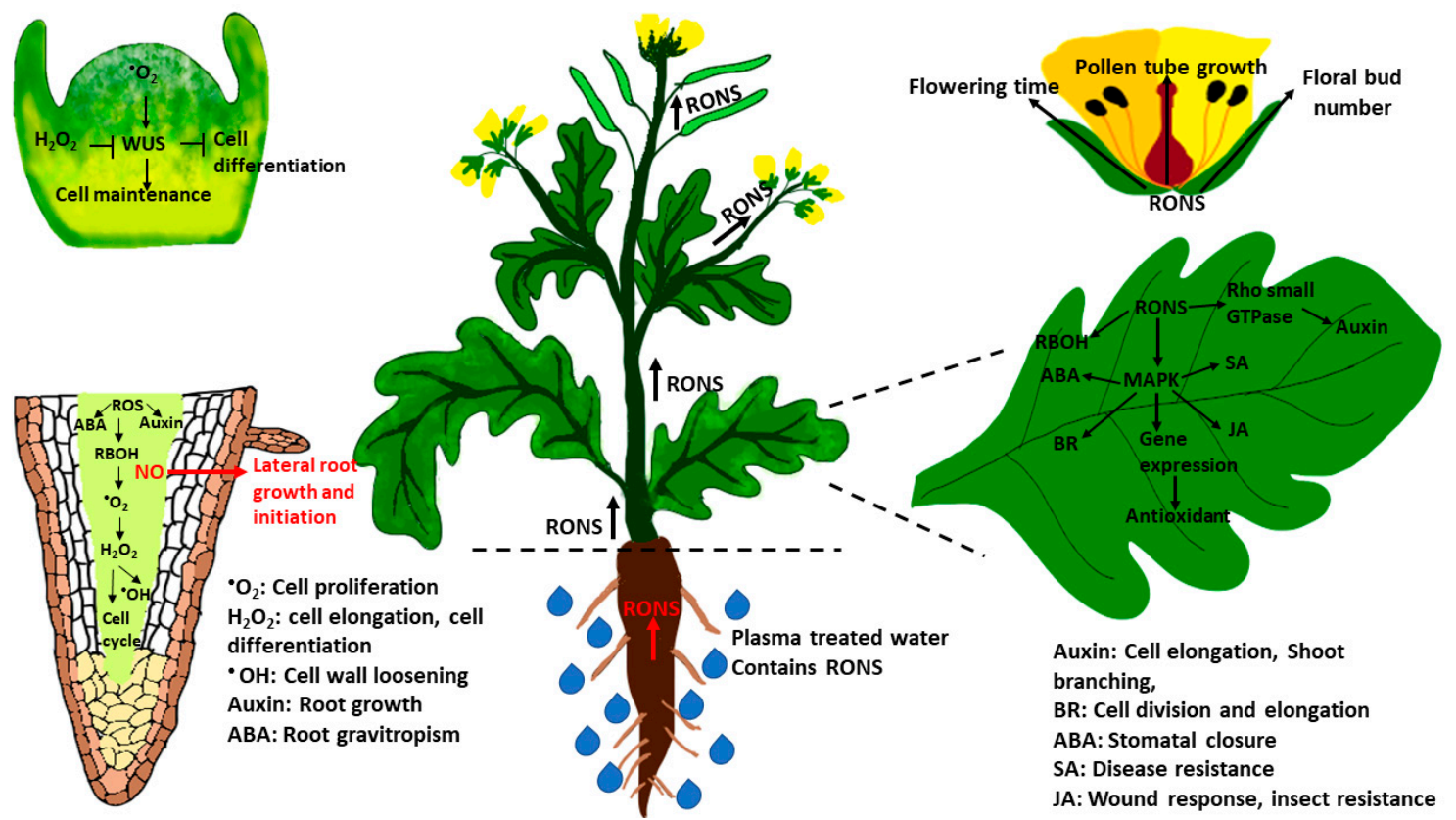

Figure 2. Effects of plasma-generated reactive oxygen and nitrogen species (RONS) in different plant organs at different growth stages. Direct and indirect exposure to plasma induces RONS in various plant organs (shoots, roots, leaves, and flowers) and activates different signaling cascades that crosstalk with other small signaling molecules and hormones to affect growth, development, and immunity. BR: Brassinosteroid, ABA: Abscisic acid, SA: Salicylic acid, JA: Jasmonic acid, MAPK: Mitogen activated protein kinase, WUS: WUSCHEL.

\section{Plasma Technology for Crop Sustainability and Food Processing}

Sustainable crop production and food security are important issues for modern society. Therefore, the development of technologies to address these issues is urgently needed. Sustainable agriculture technologies can not only increase crop production and tolerance but also help to preserve natural resources and ecosystems. Cold atmospheric or low pressure plasma is a modern-age technique that may alleviate the risks associated with agriculture and food processing systems. Cold atmospheric or low pressure plasma is an eco-friendly approach that positively affects crop production under adverse conditions. Various biotic and abiotic factors affect crop production, and several old agrochemical and biotechnological approaches have been used to address these issues. However, they often have negative impacts on the ecosystem. Plasma represents a risk-free approach because it requires low energy, is waste-free, and has no negative effects on the environment.

The effects of cold atmospheric or low pressure plasma treatment on seed germination and seedling growth under drought, salt, and chemical toxicity have been currently more studied (Table 3). 
Table 3. Effects of plasma on pre- and post-harvest plant sustainability.

\begin{tabular}{|c|c|c|c|c|c|}
\hline Plant Species & Plasma Source & Feeder Gas & $\begin{array}{l}\text { Treated } \\
\text { Stage }\end{array}$ & Improved Effects & Reference \\
\hline \multicolumn{6}{|c|}{ Pre-harvest tolerance to biotic stresses } \\
\hline Solanum lycopersicum & RF helium plasma & Helium $(\mathrm{He})$ & Seed & $\begin{array}{l}\text { Bacterial wilt } \\
\text { resistance }\end{array}$ & [85] \\
\hline Glycine max & $\begin{array}{c}\mathrm{DBD} \mathrm{O}_{2} \text { and } \mathrm{N}_{2} \\
\text { plasma }\end{array}$ & $\begin{array}{l}\text { Oxygen }\left(\mathrm{O}_{2}\right) \text { and } \\
\text { nitrogen }\left(\mathrm{N}_{2}\right)\end{array}$ & Seed & $\begin{array}{l}\text { Diaporthe/Phomopsis } \\
\text { fungal resistance }\end{array}$ & [87] \\
\hline $\begin{array}{l}\text { Solanum lycopersicum } \\
\mathrm{cv} \text {. Moneymaker and } \\
\text { VF010 }\end{array}$ & $\begin{array}{l}\text { Plasma-activated } \\
\text { water }\end{array}$ & Ambient air & Seedling & $\begin{array}{l}\text { Bacterial leaf spot } \\
\text { resistance }\end{array}$ & [88] \\
\hline \multicolumn{6}{|c|}{ Pre-harvest tolerance to abiotic stresses } \\
\hline Brassica napus & He plasma discharge & Helium (He) & Seed & $\begin{array}{l}\text { Drought stress } \\
\text { tolerance }\end{array}$ & [84] \\
\hline Pisum satioum $\mathrm{L}$. & Coplanar DBD plasma & Ambient Air & Seed & $\begin{array}{l}\text { Tolerance to } \\
\text { zeocinLess DNA } \\
\text { damage }\end{array}$ & [89] \\
\hline Arabidopsis thaliana & DBD air plasma & Air and helium $(\mathrm{He})$ & Seed & Salt stress tolerance & [90] \\
\hline Triticum aestivum & $\begin{array}{l}\text { Low-pressure } \mathrm{DBD} \\
\text { plasma with } \mathrm{Ar} / \mathrm{O}_{2} \\
\text { and } \mathrm{Ar} / \text { air gases }\end{array}$ & $\begin{array}{l}\text { Argon }(\mathrm{Ar}) / \text { oxygen }\left(\mathrm{O}_{2}\right) \\
\text { and argon }(\mathrm{Ar}) / \mathrm{air} \\
\text { mixture }\end{array}$ & Seed & $\begin{array}{l}\text { Tolerance to } \\
\text { cadmium }(\mathrm{Cd})\end{array}$ & [91] \\
\hline Hordeum vulgare & $\begin{array}{c}\text { Plasma-activated } \\
\text { water }\end{array}$ & Nitrogen $\left(\mathrm{N}_{2}\right)$ & Seed & $\begin{array}{l}\text { Tolerance to low } \\
\text { temperature and } \\
\text { hypoxia }\end{array}$ & [92] \\
\hline Solanum lycopersicum & Air Plasma Jet & Air & Seed & $\begin{array}{l}\text { Tolerance to PEG } \\
\text { (polyethlene } \\
\text { glycol)-mediated } \\
\text { drought stress }\end{array}$ & [93] \\
\hline \multicolumn{6}{|c|}{ Post-harvest sanitation } \\
\hline $\begin{array}{l}\text { Lactuca sativaBrassica } \\
\text { oleracea sp. Capitata }\end{array}$ & $\begin{array}{l}\text { Cold oxygen plasma } \\
\text { lamp (Photoplasma, } \\
\text { Model: Induct ID60) }\end{array}$ & Oxygen $\left(\mathrm{O}_{2}\right)$ & $\begin{array}{l}\text { Lettuce and } \\
\text { cabbage } \\
\text { vegetables }\end{array}$ & $\begin{array}{l}\text { L. monocytogenes } \\
\text { biofilm removal }\end{array}$ & [94] \\
\hline Blueberries & AC plasma jet & Air & $\begin{array}{l}\text { Blueberry } \\
\text { fruits }\end{array}$ & $\begin{array}{l}\text { Removed microbial } \\
\text { contamination }\end{array}$ & [95] \\
\hline Strawberries & $\begin{array}{l}\text { Plasma-activated } \\
\text { water }\end{array}$ & $\begin{array}{l}\text { Argon }(\mathrm{Ar}) / \text { oxygen }\left(\mathrm{O}_{2}\right) \\
\text { mixture }\end{array}$ & $\begin{array}{l}\text { Strawberry } \\
\text { fruits }\end{array}$ & $\begin{array}{l}\text { Removed microbial } \\
\text { contamination }\end{array}$ & [96] \\
\hline $\begin{array}{l}\text { Cucumis melo L. var. } \\
\text { Reticolatus cv. } \\
\text { Raptor }\end{array}$ & DBD plasma & Air & Melon fruits & $\begin{array}{l}\text { Removed microbial } \\
\text { contamination }\end{array}$ & [97] \\
\hline Red chicory & DBD plasma & Air & $\begin{array}{l}\text { Chicory } \\
\text { vegetables }\end{array}$ & $\begin{array}{l}\text { Reduced microbial } \\
\text { contamination }\end{array}$ & [98] \\
\hline $\begin{array}{l}\text { Lycopersicum } \\
\text { esculentum Mill. }\end{array}$ & $\begin{array}{l}\text { Intermittent corona } \\
\text { discharge plasma jet }\end{array}$ & Air & $\begin{array}{l}\text { Cherry } \\
\text { tomato fruits }\end{array}$ & $\begin{array}{l}\text { Reduced microbial } \\
\text { contamination and } \\
\text { increased shelf life }\end{array}$ & [99] \\
\hline $\begin{array}{l}\text { Apple cv. Granny } \\
\text { Smith }\end{array}$ & $\begin{array}{l}\text { Low-pressure plasma } \\
\text { (expanded plasma } \\
\text { cleaner PDC-001/002) }\end{array}$ & $\begin{array}{l}\text { Argon (Ar), nitrogen } \\
\text { (N2), oxygen (O2), and } \\
\text { Argon-oxygen (Ar-O2) }\end{array}$ & Apple fruits & $\begin{array}{l}\text { Removed microbial } \\
\text { contamination }\end{array}$ & [100] \\
\hline \multicolumn{6}{|c|}{ Post-harvest quality } \\
\hline $\begin{array}{c}\text { Actinidia deliciosa cv. } \\
\text { Hayward }\end{array}$ & DBD plasma & Air & Kiwi fruits & $\begin{array}{c}\text { Improved visual } \\
\text { quality and extended } \\
\text { storage life }\end{array}$ & [101] \\
\hline Agaricus bisporus & $\begin{array}{c}\text { Plasma } \\
\text { jetPlasma-activated } \\
\text { water }\end{array}$ & Argon-oxygen (Ar-O2) & $\begin{array}{l}\text { Button } \\
\text { mushrooms }\end{array}$ & $\begin{array}{l}\text { Reduced microbial } \\
\text { contamination and } \\
\text { delayed softening }\end{array}$ & [102] \\
\hline Radish sprouts & Microwave $\mathrm{N}_{2}$ plasma & Nitrogen $\left(\mathrm{N}_{2}\right)$ & $\begin{array}{l}\text { Radish sprout } \\
\text { vegetables }\end{array}$ & $\begin{array}{l}\text { Reduced moisture } \\
\text { content during } \\
\text { storage without } \\
\text { changing antioxidant } \\
\text { activity or ascorbic } \\
\text { acid concentration. }\end{array}$ & [103] \\
\hline
\end{tabular}


Table 3. Cont.

\begin{tabular}{cccccc}
\hline Plant Species & Plasma Source & Feeder Gas & $\begin{array}{c}\text { Treated } \\
\text { Stage }\end{array}$ & Improved Effects & Reference \\
\hline Mandarins & $\begin{array}{c}\text { Microwave } \mathrm{N}_{2}, \mathrm{He}, \mathrm{N}_{2} \\
+\mathrm{O}_{2} \text { plasma }\end{array}$ & $\begin{array}{c}\text { Nitrogen }\left(\mathrm{N}_{2}\right) \text {, helium } \\
(\text { He) and nitrogen } \\
\left(\mathrm{N}_{2}\right) / \text { oxygen }\left(\mathrm{O}_{2}\right) \\
\text { mixture }\end{array}$ & $\begin{array}{c}\text { Mandarin } \\
\text { fruits }\end{array}$ & $\begin{array}{c}\text { Increased } \\
\text { antioxidant activity } \\
\text { and phenolic content }\end{array}$ & {$[104]$} \\
Mung bean sprouts & $\begin{array}{c}\text { Plasma-activated } \\
\text { water }\end{array}$ & Air & $\begin{array}{c}\text { Mung bean } \\
\text { sprout } \\
\text { vegetables }\end{array}$ & $\begin{array}{c}\text { Reduced microbial } \\
\text { contamination } \\
\text { without changing } \\
\text { polyphenolic and } \\
\text { flavonoid contents. }\end{array}$ & {$[105]$} \\
\hline
\end{tabular}

Several studies have shown improved tolerance to abiotic stress after plasma treatment. Ling et al. [84] treated the seeds of two Brassica napus cultivars (Zhongshuang 7, a drought-sensitive cultivar, and Zhongshuang 11, a drought-resistant cultivar) with helium plasma and found that plasma treatment enhanced seed germination under 15\% (w/v) PEG 6000-mediated drought conditions. Similarly, the seeds of two Arabidopsis mutants, gl2 and gpat5, were exposed to DBD air plasma, and he seed germination efficiency was assessed under salt stress. Plasma causes structural changes to the mantle layers of the seed coat, which reduces permeability and diminishes the effects of salt stress on seed germination [90]. Upregulation of the drought stress-regulating transcription factor (WRKY) and secondary metabolites in plasma-treated seedlings was reported by Iranbakhsh et al. [106]. More recently, Adhikari et al. [93] demonstrated that cold atmospheric pressure plasma seed priming induces drought stress tolerance in seedlings-improved growth and biochemical alterations were observed in the cold plasma-primed tomato seedlings under 30\% PEG-mediated drought stress. Other reports have shown that the plasma-activated water irrigation of barley improves hypoxia and low-temperature stress tolerance [92]. Pollutant soil contamination is a major concern in agriculture; the Air/Ar cold low pressure plasma treatment of wheat seeds reduced the accumulation of Cd during germination. This is because plasma treatment modifies the seed coat and reduces the $\mathrm{pH}$ of wheat seeds, resulting in Cd detoxification [91].

Plasma can promote plant tolerance to biotic stressors, such as pathogens and pests. Pathogenic diseases severely damage crop yield and are a major threat to food security. Cold low pressure plasma treatment of tomato seeds reduced bacterial wilt disease (causal agent: Ralstonia solanacearum) at the early vegetative stage [85]. Seed-borne pathogens, such as Fusarium fujikuroi (Bakanae disease) and Burkholderia plantarii (bacterial blight), can also be controlled by cold atmospheric pressure plasma irradiation on rice [107]. Many researchers have reported the inactivation of phytogenic bacteria on seeds and the upregulation of pathogen resistance genes in plants after cold atmospheric pressure plasma exposure $[49,87]$. Plasma-activated water irrigation induced the tomato plant defense system against Xanthomonas vesicatoria $(\mathrm{Xv})$, although antimicrobial effects of the PAW against $X$. vesicatoria were not observed [88]. The induced expression of the PAL transcript upon PAW irrigation may be associated with the induced tomato defense system [88].

Harvesting, storage, and processing are crucial steps in the agricultural system. Food processing involves the transportation, cleaning, sorting, blending, and milling of crops to convert them to food. Technological innovations for the post-harvest storage and food processing stages are required to increase the food security index of the current agricultural system. Cold atmospheric or low pressure plasma is a promising technology to decontaminate and improve the shelf life of fresh and processed food products [108]. Several studies have reported plasma effects on post-harvest storage and food processing (Table 3). Microbial contamination during processing, packaging, and storing is a major problem that decreases shelf life, deteriorates taste, and causes food poisoning. Plasma treatment efficiently reduces the microbial contaminants on fruit, vegetables, and other edible products in a time- or dose-dependent manner, as summarized in a recent review [109]. The antimicrobial potential of plasma is well demonstrated by various cold atmospheric or low pressure plasma sources 
(gliding arc discharge, cold plasma argon jet, helium jet, microwave-generated plasma, and dielectric barrier discharge (DBD) plasma), microbes (Erwinia carotovora, Salmonella anatum, Salmonella enterica serovar Stanley, Salmonella enteritidis, Escherichia coli, Erwinia amylovor, Listeria monocytogenes, Clavibacter michiganensis subsp. Sepedonicus, Dickeya solani, X. campestris pv. Campestris, P. atrosepticum, Pectobacterium carotovorum subsp. Carotovorum, Pseudomonas fluorescens, Pseudomonas marginalis, and P. carotovorum), and fresh products (lettuce, tomatoes, carrots, cherries, figs, black peppers, strawberries, onions, radishes, cress, alfalfa seeds, grapes, bananas, and almonds). Studies have also shown that plasma cannot completely eradicate the microbial load but does prevent the microbes from multiplying [109]. An industrial-based DBD prototype efficiently removed the microflora load of fresh cherry tomatoes and prolonged the shelf life during storage [110]. Plasma-processed air can also reduce the microbial loads of fresh fruits/vegetables and packaged foods [111].

In the food processing industry, conventional techniques such as pasteurization, drying, and freezing, and newer physical strategies, such as ultraviolet (UV) irradiation, X-ray irradiation, ozone washing, and high-pressure processing, have been used to maintain food quality. However, these processing techniques have some drawbacks [112]. In plasma-mediated food processing, cold atmospheric or low pressure plasma can sterilize the food without compromising its flavor, odor, color, and prolonged shelf life. These plasma attributes have attracted the attention of food industry researchers. A comparison of different beverage processing techniques found that the plasma method retained the contents of ascorbic, chlorogenic, sinapic, and gallic acids in a tomato beverage, whereas pasteurization and other non-thermal methods resulted in reduced levels of these same acids [113]. Gas-phase plasma maintained the levels of phenolic compounds and hydroxycinnamic acids and reduced the anthocyanin content $(23 \%)$, suggesting that anthocyanin is susceptible to the reactive oxygen species produced by cold atmospheric pressure plasma in juice [114]. The color and texture of food are very important to consumers, and studies have shown that plasma treatment has only minor (or no) effects on the color and texture of fruits. Misra et al. [115] used a DBD cold plasma source to process packaged strawberries and observed no changes in the firmness or color, but there was a significant reduction in the microbial load. Similarly, the qualitative attributes of fresh-cut fruit (apple and melon) were not affected by plasma treatment under storage conditions [97,116]. Other food qualities, such as $\mathrm{pH}$, acidity, antioxidants, and the contents of soluble sugar and vitamins, have also been investigated after plasma treatment. About $\mathrm{pH}$, the $\mathrm{pH}$ changed due to the reactive oxygen species generated on food after plasma treatment. On the other hand, the $\mathrm{pH}$ did not change after plasma treatment because of the buffering capacity of the liquid in living tissue and the physiological activity of removing the acid from the surface [117]. The soluble sugar content is important for the taste of fruit and their juices cold atmospheric pressure plasma reduced the fructose and glucose contents and increased the sucrose content in fruit juices $[118,119]$. This is because the reactive species generated by plasma promotes ozonolysis reactions, which breaks the glycosidic bond of oligosaccharides and reduces the sugars via oxidation $[119,120]$. The vitamin contents of fruit and their juices are stable under plasma treatment [116], while the antioxidant activities of fresh food are variably influenced by cold atmospheric pressure plasma treatments, depending on the food products, plasma sources, treatment conditions, and doses [117].

\section{Future Prospects and Conclusions}

The effects of cold atmospheric or low pressure plasma on plant growth, development, and sustainability have been verified by abundant experimental data. The accumulated data suggest that cold atmospheric or low pressure plasma may provide a reliable method to reduce the risks associated with global climate change and changing agricultural environments. Changes to the traditional agriculture system and practices are inevitable "modern agriculture" has been used to designate this transition. Indoor agriculture, hydroponic culturing, and smart farming associated with ICT (Information and Communication Technology) are frequently used in modern agriculture. Cold atmospheric or low pressure plasma may also contribute to the technological innovations of 
modern agriculture. For example, plasma applications in indoor and greenhouse cultivation systems are practically possible. Cold atmospheric or low pressure plasma is environmentally and biologically safe and requires little energy compared to other radiation-based technologies. The search for application ways and area to maximize plasma's advantages should be continued. Recently, plasma-mediated improvements to plant tolerance against abiotic and biotic stresses has drawn great interest because of the influence of climate changes on agriculture. Conventional gene editing strategies are limited by safety concerns and the complexity of gene regulation networks, thus presenting an opportunity for cold atmospheric or low pressure plasma applications.

The efficient application of cold atmospheric or low pressure plasma requires experimental evidence and mechanistic studies. Although enhanced plant vitality and development due to plasma treatments have been well documented, evidence for the applied usage of plasma in agricultural fields and facilities is still lacking. Moreover, available experimental data are biased toward laboratory conditions. Thus, field and facility application studies are required. The underlying mechanisms of the plasma effects are also relatively unexplored compared to phenotypic effects discussed here. More information about the modes of plasma action on plant production and sustainability is necessary to optimize and upgrade the plasma systems and applications.

Author Contributions: All authors have written, read, and agreed to the published version of the manuscript.

Funding: This work was supported by the R \& D program of the 'Plasma Advanced Technology for Agriculture and Food (Plasma Farming)' through the National Fusion Research Institute of Korea (NFRI; funded by governmental funds). This work was partially supported by the National Research Foundation of Korea (NRF) (2016K1A4A3914113, 2020R1F1A107094211).

Conflicts of Interest: The authors declare no conflict of interest.

\section{References}

1. Arora, N.K. Impact of climate change on agriculture production and its sustainable solutions. Environ. Sustain. 2019, 2, 95-96. [CrossRef]

2. Bebber, D.P.; Ramotowski, M.A.T.; Gurr, S.J. Crop pests and pathogens move polewards in a warming world. Nat. Clim. Chang. 2013, 3, 985-988. [CrossRef]

3. Velásquez, A.C.; Castroverde, C.D.M.; He, S.Y. Plant-pathogen warfare under changing climate conditions. Curr. Biol. 2018, 28, R619-R634. [CrossRef]

4. Pathak, T.; Maskey, M.L.; Dahlberg, J.A.; Kearns, F.; Bali, K.M.; Zaccaria, D. Climate change trends and impacts on California agriculture: A detailed review. Agronomy 2018, 8, 25. [CrossRef]

5. Anderson, R.; Bayer, P.E.; Edwards, D. Climate change and the need for agricultural adaptation. Curr. Opin. Plant Biol. 2019, 13, 1-6. [CrossRef] [PubMed]

6. Ito, M.; Oh, J.-S.; Ohta, T.; Shiratani, M.; Hori, M. Current status and future prospects of agricultural applications using atmospheric-pressure plasma technologies. Plasma Process. Polym. 2017, 2017, e1700073. [CrossRef]

7. Nonogaki, H. Seed dormancy and germination-Emerging mechanisms and new hypotheses. Front. Plant Sci. 2014, 5, 233. [CrossRef] [PubMed]

8. Dubinov, A.; Lazarenko, E.; Selemir, V. Effect of glow discharge air plasma on grain crops seed. IEEE Trans. Plasma Sci. 2000, 28, 180-183. [CrossRef]

9. Volin, J.C.; Denes, F.S.; Young, R.A.; Park, S.M.T. Modification of seed germination performance through cold plasma chemistry technology. Crop Sci. 2000, 40, 1706-1718. [CrossRef]

10. Meiqiang, Y.; Mingjing, H.; Buzhou, M.; Tengcai, M. Stimulating effects of seed treatment by magnetized plasma on tomato growth and yield. Plasma Sci. Technol. 2005, 7, 3143-3147. [CrossRef]

11. Šerá, B.; Stranák, V.; Serý, M.; Tichý, M.; Spatenka, P. Germination of Chenopodium Album in response to microwave plasma treatment. Plasma Sci. Technol. 2008, 10, 506-511. [CrossRef]

12. Šerá, B.; Šerý, M.; Štrañák, V.; Špatenka, P.; Tichý, M. Does cold plasma affect breaking dormancy and seed germination? A study on seeds of Lamb's quarters (Chenopodium album agg.). Plasma Sci. Technol. 2009, 11, 750-754. [CrossRef] 
13. Šerá, B.; Špatenka, P.; Šerý, M.; Vrchotova, N.; Hruskova, I. Influence of plasma treatment on wheat and oat germination and early growth. IEEE Trans. Plasma Sci. 2010, 38, 2963-2967. [CrossRef]

14. Filatova, I.I.; Azharonok, V.V.; Kadyrov, M.A.; Beljavsky, V.; Gvozdov, A.; Shik, A.; Antonuk, A.E.; Belarus, N. The effect of plasma treatment of seeds of some grain and legumes on their sowing quality and productivity. Rom. Rep. Phys. 2011, 56, 139-143.

15. Zhou, Z.; Huang, Y.; Yang, S.; Chen, W. Introduction of a new atmospheric pressure plasma device and application on tomato seeds. Agric. Sci. 2011, 2, 23-27. [CrossRef]

16. Bormashenko, E.; Grynyov, R.; Bormashenko, Y.; Drori, E. Cold radiofrequency plasma treatment modifies wettability and germination speed of plant seeds. Sci. Rep. 2012, 2, 741. [CrossRef]

17. Šerá, B.; Gajdova, I.; Cernak, M.; Gavril, B.; Hnatiuc, E.; Kovacik, D.; Kriha, V.; Slama, J.; Šerý, M.; Špatenka, P. How various plasma sources may affect seed germination and growth. In Proceedings of the 13th International Conference on Optimization of Electrical and Electronic Equipment (OPTIM), Brasov, Romania, 24-26 May 2012; IEEE: Piscataway, NJ, USA, 2012; pp. 1365-1370. [CrossRef]

18. Ling, L.; Jiafeng, J.; Jiangang, L.; Minchong, S.; Xin, H.; Hanliang, S.; Yuanhua, D. Effects of cold plasma treatment on seed germination and seedling growth of soybean. Sci. Rep. 2014, 4, 5859. [CrossRef]

19. Mihai, A.L.; Dobrin, D.; Magureanu, M.; Popa, M.E. Possitive effect of non-thermal plasma treatment on radish seed. Rom. Rep. Phys. 2014, 66, 1110-1117.

20. Tong, J.; He, R.; Zhang, X.; Zhan, R.; Chen, W.; Yang, S. Effects of atmospheric pressure air plasma pretreatment on the seed germination and early growth of Andrographis paniculata. Plasma Sci. Technol. 2014, 16, 260-266. [CrossRef]

21. Bußler, S.; Herppich, W.B.; Neugart, S.; Schreiner, M.; Ehlbeck, J.; Rohn, S.; Schlüter, O. Impact of cold atmospheric pressure plasma on physiology and flavonol glycoside profile of peas (Pisum sativum "Salamanca”). Food Res. Int. 2015, 76, 132-141. [CrossRef]

22. Dobrin, D.; Magureanu, M.; Mandache, N.B.; Ionita, M. The effect of non-thermal plasma treatment on wheat germination and early growth. Innov. Food Sci. Emerg. Technol. 2015, 29, 255-260. [CrossRef]

23. Hayashi, N.; Ono, R.; Shiratani, M.; Yonesu, A. Antioxidative activity and growth regulation of Brassicaceae induced by oxygen radical irradiation. Jpn. J. Appl. Phys. 2015, 54, 6. [CrossRef]

24. Ji, S.H.; Kim, T.; Panngom, K.; Hong, Y.J.; Pengkit, A.; Park, D.H.; Kang, M.H.; Lee, S.H.; Im, J.S.; Kim, J.S.; et al. Assessment of the effects of nitrogen plasma and plasma-generated nitric oxide on early development of Coriandum sativum. Plasma Process. Polym. 2015, 12, 1164-1173. [CrossRef]

25. Ono, R.; Hayashi, N. Variation of antioxidative activity and growth enhancement of Brassicaceae induced by low-pressure oxygen plasma. Jpn. J. Appl. Phys. 2015, 54, 06GD03. [CrossRef]

26. Peethambaran, B.; Han, J.; Kermalli, K.; Jiaxing, J.; Fridman, G.; Balsamo, R.; Fridman, A.A.; Miller, V. Nonthermal plasma reduces water consumption while accelerating Arabidopsis thaliana growth and fecundity. Plasma Med. 2015, 5, 87-98. [CrossRef]

27. Stolárik, T.; Henselová, M.; Martinka, M.; Novák, O.; Zahoranová, A.; Černák, M. Effect of low-temperature plasma on the structure of seeds, growth and metabolism of endogenous phytohormones in pea (Pisum sativum L.). Plasma Chem. Plasma Process. 2015, 35, 659-676. [CrossRef]

28. Ji, S.H.; Choi, K.H.; Pengkit, A.; Im, J.S.; Kim, J.S.; Kim, Y.H.; Park, Y.; Hong, E.J.; Jung, S.K.; Choi, E.H.; et al. Effects of high voltage nanosecond pulsed plasma and micro DBD plasma on seed germination, growth development and physiological activities in spinach. Arch. Biochem. Biophys. 2016, 605, 117-128. [CrossRef]

29. Junior, C.A.; de Oliveira Vitoriano, J.O.; da Silva, D.L.S.; de Lima Farias, M.; de Lima Dantas, M.B. Water uptake mechanism and germination of Erythrina velutina seeds treated with atmospheric plasma. Sci. Rep. 2016, 6, 33722. [CrossRef]

30. Park, Y.; Oh, K.S.; Oh, J.; Seok, D.C.; Kim, S.B.; Yoo, S.J.; Lee, M.-J. The biological effects of surface dielectric barrier discharge on seed germination and plant growth with barley. Plasma Process. Polym. 2016, 15, 1600056. [CrossRef]

31. Sarinont, T.; Amano, T.; Attri, P.; Koga, K.; Hayashi, N.; Shiratani, M. Effects of plasma irradiation using various feeding gases on growth of Raphanus sativus L. Arch. Biochem. Biophys. 2016, 605, 129-140. [CrossRef] [PubMed]

32. Zhou, R.; Zhou, R.; Zhang, X.; Zhuang, J.; Yang, S.; Bazaka, K.; Ostrikov, K. Effects of atmospheric-pressure $\mathrm{N}_{2}, \mathrm{He}$, Air, and $\mathrm{O}_{2}$ microplasmas on mung bean seed germination and seedling growth. Sci. Rep. 2016, 6, 32603. [CrossRef] [PubMed] 
33. Dubinov, A.E.; Kozhayeva, J.P.; Zuimatch, E.A. Changing germination rate of brown mustard seeds after treatment with plasmas of nanosecond electric discharges. IEEE Trans. Plasma Sci. 2017, 45, 294-300. [CrossRef]

34. Gómez-Ramírez, A.; López-Santos, C.; Cantos, M.; García, J.L.; Molina, R.; Cotrino, J.; Espinós, J.P.; González-Elipe, A.R. Surface chemistry and germination improvement of Quinoa seeds subjected to plasma activation. Sci. Rep. 2017, 7, 5924. [CrossRef] [PubMed]

35. Meng, Y.; Qu, G.; Wang, T.; Sun, Q.; Liang, D.; Hu, S. Enhancement of germination and seedling growth of wheat seed using dielectric barrier discharge plasma with various gas sources. Plasma Chem. Plasma Process. 2017, 37, 1105-1119. [CrossRef]

36. Pawlat, J.; Starek, A.; Sujak, A.; Kwiatkowski, M.; Terebun, P.; Budzeń, M. Effects of atmospheric pressure plasma generated in GlidArc reactor on Lavatera thuringiaca L. seeds' germination. Plasma Process. Polym. 2017, 15, 1700064. [CrossRef]

37. Safari, N.; Iranbakhsh, A.; Oraghi Ardebili, Z. Non-thermal plasma modified growth and differentiation process of Capsicum annuum PP805 Godiva in in vitro conditions. Plasma Sci. Technol. 2017, 19, 055501. [CrossRef]

38. Šerá, B.; Šerý, M.; Gavril, B.; Gajdova, I. Seed germination and early growth responses to seed pre-treatment by non-thermal plasma in hemp cultivars (Cannabis sativa L.). Plasma Chem. Plasma Process. 2017, 37, $207-221$. [CrossRef]

39. Da Silva, A.R.M.; Farias, M.L.; da Silva, D.L.S.; Vitoriano, J.O.; de Sousa, R.C.; Alves-Junior, C. Using atmospheric plasma to increase wettability, imbibition and germination of physically dormant seeds of Mimosa caesalpiniafolia. Colloids Surfaces B 2017, 157, 280-285. [CrossRef]

40. Zhang, J.J.; Jo, J.O.; Huynh, D.L.; Mongre, R.K.; Ghosh, M.; Singh, A.K.; Lee, S.B.; Mok, Y.S.; Hyuk, P.; Jeong, D.K. Growth-inducing effects of argon plasma on soybean sprouts via the regulation of demethylation levels of energy metabolism-related genes. Sci. Rep. 2017, 7, 41917. [CrossRef]

41. Matra, K. Atmospheric non-thermal argon-oxygen plasma for sunflower seedling growth improvement. Jpn. J. Appl. Phys. 2018, 57, 01AG03. [CrossRef]

42. Pawlat, J.; Starek, A.; Sujak, A.; Terebun, P.; Kwiatkowski, M.; Budzeń, M.; Andrejko, D. Effects of atmospheric pressure plasma jet operating with DBD on Lavatera thuringiaca L. seeds' germination. PLoS ONE 2018, 13, e0194349. [CrossRef]

43. Rahman, M.M.; Sajib, S.A.; Rahi, M.S.; Tahura, S.; Roy, N.C.; Parvez, S.; Reza, M.A.; Talukder, M.R.; Kabir, A.H. Mechanisms and signaling associated with LPDBD plasma mediated growth improvement in wheat. Sci. Rep. 2018, 8, 10498. [CrossRef]

44. Ahn, C.; Gill, J.; Ruzic, D.N. Growth of plasma-treated corn seeds under realistic conditions. Sci. Rep. 2019, 9, 4355. [CrossRef] [PubMed]

45. Fadhlalmawla, S.A.; Mohamed, A.-A.H.; Almarashi, J.Q.; Boutraa, T. The impact of cold atmospheric pressure plasma jet on seed germination and seedlings growth of fenugreek (Trigonella foenum-graecum). Plasma Sci. Technol. 2019, 21, 105503. [CrossRef]

46. Holc, M.; Primc, G.; Iskra, J.; Titan, P.; Kovač, J.; Mozetič, M.; Junkar, I. Effect of oxygen plasma on sprout and root growth, surface morphology and yield of garlic. Plants 2019, 8, 462. [CrossRef] [PubMed]

47. Iqbal, T.; Farooq, M.; Afsheen, S.; Abrar, M.; Yousaf, M.; Ijaz, M. Cold plasma treatment and laser irradiation of Triticum spp. seeds for sterilization and germination. J. Laser Appl. 2019, 31, 42013. [CrossRef]

48. Li, L.; Guo, H.; Zong, J.; Chen, J.; Wang, Y.; Li, J.; Li, D.; Shao, H.; Liu, J. Influence of low-vacuum helium cold plasma pre-treatment on the rooting and root growth of zoysiagrass (Zoysia willd.) stolon cuttings. Plasma Sci. Technol. 2019, 21, 55504. [CrossRef]

49. Pérez-Pizá, M.C.; Prevosto, L.; Grijalba, P.E.; Zilli, C.G.; Cejas, E.; Mancinelli, B.; Balestrasse, K.B. Improvement of growth and yield of soybean plants through the application of non-thermal plasmas to seeds with different health status. Heliyon 2019, 5, e01495. [CrossRef]

50. Volkov, A.G.; Hairston, J.S.; Patel, D.; Gott, R.P.; Xu, K.G. Cold plasma poration and corrugation of pumpkin seed coats. Bioelectrochemistry 2019, 128, 175-185. [CrossRef]

51. Abedi, S.; Iranbakhsh, A.; Oraghi Ardebili, Z.O.; Ebadi, M. Seed priming with cold plasma improved early growth, flowering, and protection of Cichorium intybus against selenium nanoparticle. J. Theor. Appl. Phys. 2020, 14, 113-119. [CrossRef] 
52. Ambrico, P.F.; Šimek, M.; Ambrico, M.; Morano, M.; Prukner, V.; Minafra, A.; Allegretta, I.; Porfido, C.; Senesi, G.S.; Terzano, R. On the air atmospheric pressure plasma treatment effect on the physiology, germination and seedlings of basil seeds. J. Phys. D Appl. Phys. 2020, 53, 104001. [CrossRef]

53. Ghasempour, M.; Iranbakhsh, A.; Ebadi, M.; Ardebili, Z.O. Seed priming with cold plasma improved seedling performance, secondary metabolism, and expression of deacetylvindoline O-acetyltransferase gene in Catharanthus roseus. Contrib. Plasma Phys. 2020, 60, e201900159. [CrossRef]

54. Mujahid, Z.; Tounekti, T.; Khemira, H. Cold plasma treatment to release dormancy and improve growth in grape buds: A promising alternative to natural chilling and rest breaking chemicals. Sci. Rep. 2020, 10, 2667. [CrossRef] [PubMed]

55. Park, D.P.; Davis, K.; Gilani, S.; Alonzo, C.-A.; Dobrynin, D.; Friedman, G.; Fridman, A.; Rabinovich, A.; Fridman, G. Reactive nitrogen species produced in water by non-equilibrium plasma increase plant growth rate and nutritional yield. Curr. Appl. Phys. 2013, 13, S19-S29. [CrossRef]

56. Lindsay, A.; Byrns, B.; King, W.; Andhvarapou, A.; Fields, J.; Knappe, D.; Fonteno, W.; Shannon, S. Fertilization of radishes, tomatoes, and marigolds using a large-volume atmospheric glow discharge. Plasma Chem. Plasma Process. 2014, 34, 1271-1290. [CrossRef]

57. Sivachandiran, L.; Khacef, A. Enhanced seed germination and plant growth by atmospheric pressure cold air plasma: Combined effect of seed and water treatment. RSC Adv. 2017, 7, 1822-1832. [CrossRef]

58. Bafoil, M.; Jemmat, A.; Martinez, Y.; Merbahi, N.; Eichwald, O.; Dunand, C.; Yousfi, M. Effects of low temperature plasmas and plasma activated waters on Arabidopsis thaliana germination and growth. PLoS ONE 2018, 13, e0195512. [CrossRef]

59. Judée, F.; Simon, S.; Bailly, C.; Dufour, T. Plasma-activation of tap water using DBD for agronomy applications: Identification and quantification of long lifetime chemical species and production/consumption mechanisms. Water Res. 2018, 133, 47-59. [CrossRef]

60. Lee, E.-J.; Khan, M.S.I.; Shim, J.; Kim, Y.-J. Roles of oxides of nitrogen on quality enhancement of soybean sprout during hydroponic production using plasma discharged water recycling technology. Sci. Rep. 2018, 8, 16872. [CrossRef]

61. Adhikari, B.; Adhikari, M.; Ghimire, B.; Park, G.; Choi, E.H. Cold atmospheric plasma-activated water irrigation induces defense hormone and gene expression in tomato seedlings. Sci. Rep. 2019, 9, 16080. [CrossRef]

62. Gao, X.; Zhang, A.; Héroux, P.; Sand, W.; Sun, Z.; Zhan, J.; Wang, C.; Hao, S.; Li, Z.; Li, Z.; et al. Effect of dielectric barrier discharge cold plasma on pea seed growth. J. Agric. Food Chem. 2019, 67, 10813-10822. [CrossRef] [PubMed]

63. Iwata, N.; Gamaleev, V.; Hashizume, H.; Oh, J.; Ohta, T.; Ishikawa, K.; Hori, M.; Ito, M. Simultaneous achievement of antimicrobial property and plant growth promotion using plasma-activated benzoic compound solution. Plasma Process. Polym. 2019, 16, e1900023. [CrossRef]

64. Kang, M.H.; Jeon, S.S.; Shin, S.M.; Veerana, M.; Ji, S.-H.; Uhm, H.-S.; Choi, E.H.; Shin, J.H.; Park, G. Dynamics of nitric oxide level in liquids treated with microwave plasma-generated gas and their effects on spinach development. Sci. Rep. 2019, 9, 1011. [CrossRef]

65. Liu, B.; Honnorat, B.; Yang, H.; Arancibia, J.; Rajjou, L.; Rousseau, A. Non-thermal DBD plasma array on seed germination of different plant species. J. Phys. D Appl. Phys. 2019, 52, 025401. [CrossRef]

66. Zhou, R.; Li, J.; Zhou, R.; Zhang, X.; Yang, S. Atmospheric-pressure plasma treated water for seed germination and seedling growth of mung bean and its sterilization effect on mung bean sprouts. Innov. Food Sci. Emerg. 2019, 53, 36-44. [CrossRef]

67. Krapivina, S.A.; Filippov, A.K.; Levitskaya, T.N.; Bakhvalov, A. Gas Plasma Treatment of Plant Seeds. U.S. Patent No. US5281315A, 25 January 1994.

68. Mitra, A.; Li, Y.F.; Klämpfl, T.G.; Shimizu, T.; Jeon, J.; Morfill, G.E.; Zimmermann, J.L. Inactivation of surface-borne microorganisms and increased germination of seed specimen by cold atmospheric plasma. Food Bioprocess Technol. 2014, 7, 645-653. [CrossRef]

69. Wang, X.-Q.; Zhou, R.-W.; de Groot, G.; Bazaka, K.; Murphy, A.B.; Ostrikov, K. Spectral characteristics of cotton seeds treated by a dielectric barrier discharge plasma. Sci. Rep. 2017, 7, 5601. [CrossRef]

70. Su, L.; Lan, Q.; Pritchard, H.W.; Xue, H.; Wang, X. Reactive oxygen species induced by cold stratification promote germination of Hedysarum scoparium seeds. Plant Physiol. Bioch. 2016, 109, 406-415. [CrossRef] 
71. Mildažienė, V.; Aleknavičiūtè, V.; Žūkienè, R.; Paužaitè, G.; Naučienè, Z.; Filatova, I.; Lyushkevich, V.; Haimi, P.; Tamošiūnè, I.; Baniulis, D. Treatment of common sunflower (Helianthus annus L.) seeds with radio-frequency electromagnetic field and cold plasma induces changes in seed phytohormone balance, seedling development and leaf protein expression. Sci. Rep. 2019, 9, 6437. [CrossRef]

72. Huijser, P.; Schmid, M. The control of developmental phase transitions in plants. Development 2011, 138, 4117-4129. [CrossRef]

73. Kumar, R.; Thakur, A.K.; Vikram, A.; Vaid, A.; Rane, R. Effect of plasma treatment on growth and yield of okra [Abelmoschus esculentus (L.) under field conditions. Int. J. Bio-Resour. Stress Manag. 2017, 8, 659-667. [CrossRef]

74. Li, L.; Li, J.; Shao, H.; Dong, Y. Effects of low-vacuum helium cold plasma treatment on seed germination, plant growth and yield of oilseed rape. Plasma Sci. Technol. 2018, 20, 095502. [CrossRef]

75. Seddighinia, F.S.; Iranbakhsh, A.; Oraghi Ardebili, Z.; Nejad Satari, T.; Soleimanpour, S. Seed priming with cold plasma and multi-walled carbon nanotubes modified growth, tissue differentiation, anatomy, and yield in bitter melon (Momordica charantia). J. Plant Growth Regul. 2019, 39, 87-98. [CrossRef]

76. Mhamdi, A.; Van Breusegem, F. Reactive oxygen species in plant development. Development 2018, 145, 1-12. [CrossRef] [PubMed]

77. Huang, H.; Ullah, F.; Zhou, D.-X.; Yi, M.; Zhao, Y. Mechanisms of ROS regulation of plant development and stress responses. Front. Plant Sci. 2019, 10, 800. [CrossRef]

78. de Simone, A.; Hubbard, R.; de la Torre, N.V.; Velappan, Y.; Wilson, M.; Considine, M.J.; Soppe, W.J.J.; Foyer, C.H. Redox changes during the cell cycle in the embryonic meristem of Arabidopsis thaliana. Antioxid. Redox Signal. 2017, 27, 1505-1519. [CrossRef]

79. Tognetti, V.B.; Bielach, A.; Hrtyan, M. Redox regulation at the site of primary growth: Auxin, cytokinin and ROS crosstalk. Plant Cell Environ. 2017, 40, 2586-2605. [CrossRef]

80. Livanos, P.; Galatis, B.; Quader, H.; Apostolakos, P. Disturbance of reactive oxygen species homeostasis induces atypical tubulin polymer formation and affects mitosis in root-tip cells of Triticum turgidum and Arabidopsis thaliana. Cytoskeleton 2012, 69, 1-21. [CrossRef]

81. Tsukagoshi, H. Control of root growth and development by reactive oxygen species. Curr. Opin. Plant Biol. 2016, 29, 57-63. [CrossRef]

82. Hu, L.; Liang, W.; Yin, C.; Cui, X.; Zong, J.; Wang, X.; Hu, J.; Zhang, D. Rice MADS3 regulates ROS homeostasis during late anther development. Plant Cell 2011, 23, 515-533. [CrossRef]

83. Tian, Y.; Fan, M.; Qin, Z.; Lv, H.; Wang, M.; Zhang, Z.; Zhou, W.; Zhao, N.; Li, X.; Han, C.; et al. Hydrogen peroxide positively regulates brassinosteroid signaling through oxidation of the BRASSINAZOLE-RESISTANT1 transcription factor. Nat. Commun. 2018, 9, 1063. [CrossRef] [PubMed]

84. Ling, L.; Jiangang, L.; Minchong, S.; Chunlei, Z.; Yuanhua, D. Cold plasma treatment enhances oilseed rape seed germination under drought stress. Sci. Rep. 2015, 5, 13033. [CrossRef] [PubMed]

85. Jiang, J.; Lu, Y.; Li, J.; Li, L.; He, X.; Shao, H.; Dong, Y. Effect of seed treatment by cold plasma on the resistance of tomato to Ralstonia solanacearum (Bacterial Wilt). PLoS ONE 2014, 9, e97753. [CrossRef] [PubMed]

86. Buonopane, G.J.; Antonacci, C.; Lopez, J. Effect of cold plasma processing on botanicals and their essential oils. Plasma Med. 2016, 6, 315-324. [CrossRef]

87. Pérez Pizá, M.C.; Prevosto, L.; Zilli, C.; Cejas, E.; Kelly, H.; Balestrasse, K. Effects of non-thermal plasmas on seed-borne Diaporthe/Phomopsis complex and germination parameters of soybean seeds. Innov. Food Sci. Emerg. Technol. 2018, 49, 82-91. [CrossRef]

88. Perez, S.M.; Biondi, E.; Laurita, R.; Proto, M.; Sarti, F.; Gherardi, M.; Bertaccini, A.; Colombo, V. Plasma activated water as resistance inducer against bacterial leaf spot of tomato. PLoS ONE 2019, 14, e0217788. [CrossRef]

89. Kyzek, S.; Holubová, Ĺ.; Medvecká, V.; Tomeková, J.; Gálová, E.; Zahoranová, A. Cold atmospheric pressure plasma can induce adaptive response in pea seeds. Plasma Chem. Plasma Process. 2018, 39, 475-486. [CrossRef]

90. Bafoil, M.; Le Ru, A.; Merbahi, N.; Eichwald, O.; Dunand, C.; Yousfi, M. New insights of low-temperature plasma effects on germination of three genotypes of Arabidopsis thaliana seeds under osmotic and saline stresses. Sci. Rep. 2019, 9, 8649. [CrossRef]

91. Kabir, A.H.; Rahman, M.M.; Das, U.; Sarkar, U.; Roy, N.C.; Reza, M.A.; Talukdar, M.R.; Uddin, M.A. Reduction of cadmium toxicity in wheat through plasma technology. PLoS ONE 2019, 14, e0214509. [CrossRef] 
92. Gierczik, K.; Vukušić, T.; Kovács, L.; Székely, A.; Szalai, G.; Milošević, S.; Kocsy, G.; Kutasi, K.; Galiba, G. Plasma-activated water to improve the stress tolerance of barley. Plasma Process. Polym. 2020, 17, e1900123. [CrossRef]

93. Adhikari, B.; Adhikari, M.; Ghimire, B.; Chandra Adhikari, B.; Park, G.; Choi, E.H. Cold plasma seed priming modulates growth, redox homeostasis and stress response by inducing reactive species in tomato (Solanum lycopersicum). Free Radic. Biol. Med. 2020, 156, 57-69. [CrossRef] [PubMed]

94. Srey, S.; Park, S.Y.; Jahid, I.K.; Ha, S.-D. Reduction effect of the selected chemical and physical treatments to reduce L. monocytogenes biofilms formed on lettuce and cabbage. Food Res. Int. 2014, 62, 484-491. [CrossRef]

95. Lacombe, A.; Niemira, B.A.; Gurtler, J.B.; Fan, X.; Sites, J.; Boyd, G.; Chen, H. Atmospheric cold plasma inactivation of aerobic microorganisms on blueberries and effects on quality attributes. Food Microbiol. 2015, 46, 479-484. [CrossRef] [PubMed]

96. Ma, R.; Wang, G.; Tian, Y.; Wang, K.; Zhang, J.; Fang, J. Non-thermal plasma-activated water inactivation of food-borne pathogen on fresh produce. J. Hazard. Mater. 2015, 300, 643-651. [CrossRef]

97. Tappi, S.; Gozzi, G.; Vannini, L.; Berardinelli, A.; Romani, S.; Ragni, L.; Rocculi, P. Cold plasma treatment for fresh-cut melon stabilization. Innov. Food Sci. Emerg. Technol. 2016, 33, 225-233. [CrossRef]

98. Trevisani, M.; Berardinelli, A.; Cevoli, C.; Cecchini, M.; Ragni, L.; Pasquali, F. Effects of sanitizing treatments with atmospheric cold plasma, SDS and lactic acid on verotoxin-producing Escherichia coli and Listeria monocytogenes in red chicory (radicchio). Food Control 2017, 78, 138-143. [CrossRef]

99. Lee, T.; Puligundla, P.; Mok, C. Intermittent corona discharge plasma jet for improving tomato quality. J. Food Eng. 2018, 223, 168-174. [CrossRef]

100. Segura-Ponce, L.; Reyes, J.; Troncoso-Contreras, G.; Valenzuela-Tapia, G. Effect of low-pressure cold plasma (LPCP) on the wettability and the inactivation of Escherichia coli and Listeria innocua on fresh-cut apple (Granny Smith) skin. Food Bioprocess Technol. 2018, 11, 1075-1086. [CrossRef]

101. Ramazzina, I.; Berardinelli, A.; Rizzi, F.; Tappi, S.; Ragni, L.; Sacchetti, G.; Rocculi, P. Effect of cold plasma treatment on physico-chemical parameters and antioxidant activity of minimally processed kiwifruit. Postharvest Biol. Technol. 2015, 107, 55-65. [CrossRef]

102. Xu, Y.; Tian, Y.; Ma, R.; Liu, Q.; Zhang, J. Effect of plasma activated water on the postharvest quality of button mushrooms, Agaricus bisporus. Food Chem. 2016, 197, 436-444. [CrossRef]

103. Oh, Y.J.; Song, A.Y.; Min, S.C. Inhibition of Salmonella typhimurium on radish sprouts using nitrogen-cold plasma. Int. J. Food Microbiol. 2017, 249, 66-71. [CrossRef] [PubMed]

104. Won, M.Y.; Lee, S.J.; Min, S.C. Mandarin preservation by microwave-powered cold plasma treatment. Innov. Food Sci. Emerg. Technol. 2017, 39, 25-32. [CrossRef]

105. Xiang, Q.; Liu, X.; Liu, S.; Ma, Y.; Xu, C.; Bai, Y. Effect of plasma-activated water on microbial quality and physicochemical characteristics of mung bean sprouts. Innov. Food Sci. Emerg. Technol. 2018, 52, 49-56. [CrossRef]

106. Iranbakhsh, A.; Oraghi Ardebili, Z.; Molaei, H.; Oraghi Ardebili, N.; Amini, M. Cold plasma up-regulated expressions of WRKY1 transcription factor and genes involved in biosynthesis of cannabinoids in hemp (Cannabis sativa L.). Plasma Chem. Plasma Process. 2020, 40, 527-537. [CrossRef]

107. Ochi, A.; Konishi, H.; Ando, S.; Sato, K.; Yokoyama, K.; Tsushima, S.; Yoshida, S.; Morikawa, T.; Kaneko, T.; Takahashi, H. Management of bakanae and bacterial seedling blight diseases in nurseries by irradiating rice seeds with atmospheric plasma. Plant Pathol. 2016, 66, 67-76. [CrossRef]

108. Bourke, P.; Ziuzina, D.; Boehm, D.; Cullen, P.J.; Keener, K. The potential of cold plasma for safe and sustainable food production. Trends Biotechnol. 2018, 36, 615-626. [CrossRef]

109. Adhikari, B.; Pangomm, K.; Veerana, M.; Mitra, S.; Park, G. Plant disease control by non-thermal atmospheric-pressure plasma. Front. Plant Sci. 2020, 11, 77. [CrossRef]

110. Ziuzina, D.; Misra, N.; Cullen, P.; Keener, K.; Mosnier, J.; Vilaró, I.; Gaston, E.; Bourke, P. Demonstrating the potential of industrial scale in-package atmospheric cold plasma for decontamination of cherry tomatoes. Plasma Med. 2016, 6, 397-412. [CrossRef]

111. Schnabel, U.; Schmidt, C.; Stachowiak, J.; Bösel, A.; Andrasch, M.; Ehlbeck, J. Plasma processed air for biological decontamination of PET and fresh plant tissue. Plasma Process. Polym. 2018, 15, 1600057. [CrossRef]

112. Pan, Y.; Cheng, J.; Sun, D. Cold plasma-mediated treatments for shelf life extension of fresh produce: A review of recent research developments. Compr. Rev. Food Sci. Food Saf. 2019, 18, 1312-1326. [CrossRef] 
113. Mehta, D.; Sharma, N.; Bansal, V.; Sangwan, R.S.; Yadav, S.K. Impact of ultrasonication, ultraviolet and atmospheric cold plasma processing on quality parameters of tomato-based beverage in comparison with thermal processing. Innov. Food Sci. Emerg. Technol. 2019, 52, 343-349. [CrossRef]

114. Kovačević Bursać, D.; Gajdoš Kljusurić, J.; Putnik, P.; Vukušić, T.; Herceg, Z.; Dragović-Uzelac, V. Stability of polyphenols in chokeberry juice treated with gas phase plasma. Food Chem. 2016, 212, 323-331. [CrossRef] [PubMed]

115. Misra, N.; Patil, S.; Moiseev, T.; Bourke, P.; Mosnier, J.; Keener, K.; Cullen, P. In-package atmospheric pressure cold plasma treatment of strawberries. J. Food Eng. 2014, 125, 131-138. [CrossRef]

116. Ramazzina, I.; Tappi, S.; Rocculi, P.; Sacchetti, G.; Berardinelli, A.; Marseglia, A.; Rizzi, F. Effect of cold plasma treatment on the functional properties of fresh-cut apples. J. Agric. Food Chem. 2016, 64, 8010-8018. [CrossRef] [PubMed]

117. Pankaj, S.K.; Wan, Z.; Keener, K.M. Effects of cold plasma on food quality: A review. Foods 2018, 7, 4. [CrossRef] [PubMed]

118. Almeida, F.D.L.; Cavalcante, R.S.; Cullen, P.J.; Frias, J.M.; Bourke, P.; Fernandes, F.A.; Rodrigues, S. Effects of atmospheric cold plasma and ozone on prebiotic orange juice. Innov. Food Sci. Emerg. Technol. 2015, 32, 127-135. [CrossRef]

119. Rodríguez, Ó.; Gomes, W.F.; Rodrigues, S.; Fernandes, F.A. Effect of indirect cold plasma treatment on cashew apple juice (Anacardium occidentale L.). LWT Food Sci. Technol. 2017, 84, 457-463. [CrossRef]

120. Ben'ko, E.M.; Manisova, O.R.; Lunin, V.V. Effect of ozonation on the reactivity of lignocellulose substrates in enzymatic hydrolyses to sugars. Russ. J. Phys. Chem. A 2013, 87, 1108-1113. [CrossRef]

(C) 2020 by the authors. Licensee MDPI, Basel, Switzerland. This article is an open access article distributed under the terms and conditions of the Creative Commons Attribution (CC BY) license (http://creativecommons.org/licenses/by/4.0/). 